\title{
IMPLEMENTASI KEBIJAKAN SERTIFIKASI GURU DALAM MENINGKATKAN KINERJA GURU DI KANTOR KEMENTERIAN AGAMA KABUPATEN TEGAL
}

\author{
Sukarno \\ UIN Raden Mas Said Surakarta \\ sukarnobna@gmail.com \\ M. Munadi \\ UIN Raden Mas Said Surakarta \\ muh.munadi@iain-surakarta.ac.id \\ Abdul Matin \\ UIN Raden Mas Said Surakarta \\ abdulmatin@iain-surakarta.ac.id
}

DOI: 10.35719/jieman.v3i2.93

\begin{abstract}
Abstrak
Guru mempunyai peran sebagai profesional. Jabatan ini menuntut peningkatan kecakapan dan mutu keguruan secara berkesinambungan. Penelitian ini bertujuan untuk mendeskripsikan implementasi kebijakan sertifikasi guru di Kantor Kementerian Agama Kabupaten Tegal. Selain itu, penelitian ini akan melihat faktor-faktor apakah yang menghambat implementasi kebijakan sertifikasi guru, serta implementasi kebijakan sertifikasi guru terhadap peningkatan kinerja guru di Kantor Kementerian Agama Kabupatan Tegal. Penelitian ini menggunaka metode deskriptif kualitatif. Teknik analisis data menggunaka model interaktif. Hasil penelitian menunjukkan bahwa implementasi kebijakan sertifikasi guru di
\end{abstract}


JIEMAN: Journal of Islamic Educational Management

Kantor Kementerian Agama Kabupaten Tegal berjalan dengan baik. Berdasarkan model implementasi kebijakan Edward III yang terdiri atas empat variabel yakni komunikasi, sumber daya, disposisi, dan struktur birokrasi, maka hanya sumber daya pada dimensi staf pengelola belum mampu menjabarkan petunjuk kepala seksi dan struktur birokrasi pada dimensi kecepatan dan ketepatan pengiriman berkas yang masih perlu ditingkatkan. Faktor penghambat implementasi kebijakan sertifikasi guru di Kantor Kementerian Agama Kabupaten Tegal adalah kecenderungan staf pengelola menunggu perintah dan kurang inisiatif. Melalui program peningkatan kualitas kinerja guru tersebut terutama terhadap program sertifikasi guru, guru mampu meningkatkan terhadap penguasaan kompetensi sebagai agen pembelajaran meliputi kompetensi pedagogik, kompetensi kepribadian, kompetensi sosial, dan kompetensi professional, semua itu akan berdampak pada perbaikan kinerja guru.

Kata Kunci: kebijakan pemerintah, sertifikasi guru, kinerja guru

\section{Abstract}

Teachers have a role as professionals. This position demands the continuous improvement of skills and quality of teacher training. This research aims to describe the implementation of teacher certification policy in the Religious Affairs Office of the District Tegal. In addition, this study will look at what factors hinder the implementation of teacher certification policies, as well as the implementation of teacher certification policies towards improving teacher performance at the Religious Affairs Office of the District Tegal. This study uses qualitative descriptive methods. Data analysis techniques use interactive models. The results showed that the implementation of the teacher certification policy in the Religious Affairs Office of the District Tegal runned well. Based on the Edward III policy implementation model consisting offour variables, namely communication, resources, disposition, and bureaucratic structure, only resources in the managing staff dimension have not been able to describe the instructions of the head of the section and bureaucratic structure on the dimensions of speed and accuracy of file delivery that still need to be improved. The inhibiting factor in the implementation of teacher certification policies in the Religious Affairs Office of the District Tegal is the tendency of managing staff to wait for orders and lack initiative. Through the teacher performance improvement program, especially against teacher certification programs, teachers are 
expected to be able to improve the mastery of competence as a learning agent including pedagogical competence, personality competence, social competence, and professional competence, all of which will have an impact on improving teacher performance.

Keywords: government policy, teacher sertification, teacher performance

\section{Pendahuluan}

Dalam dunia pendidikan, salah satu cara yang ditempuh adalah menciptakan guru profesional dan memiliki kinerja baik agar mutu pendidikan dapat mencapai tujuannya dengan optimal. Program sertifikasi guru adalah cara pemerintah menjadikan guru agar semakin berkualitas, mempunyai kompetensi yang baik, serta dapat membantu kondisi perekonomian guru. ${ }^{1}$ Integritas diri serta kecakapan keguruan perlu ditumbuhkan dan dikembangkan secara terus-menerus, karena guru memiliki tugas beragam yang implementasinya dalam bentuk pengabdian. Tugas itu meliputi bidang profesi, kemanusiaan dan bidang kemasyarakatan. Peran guru dalam bidang pendidikan sangat strategis, bahkan sumber daya pendidikan lain seringkali kurang berarti apabila tidak disertai dengan kualitas guru yang memadai.

Regulasi yang digulirkan pemerintah juga tidak hanya berkaitan dengan fisik melainkan berkaitan pula dengan pemberdayaan guru karena disadari sepenuhnya bahwa betapapun lengkap sarana pendidikan, dana yang mencukupi, input (siswa) yang berkualitas, pemimpin (kepala sekolah) yang profesional, staf administrasi (tata usaha sekolah) yang handal, akan tetapi tanpa guru yang kompeten dan profesional, maka tetap tidak akan menghasilkan mutu pendidikan yang optimal karena guru merupakan bagian terpenting dalam proses belajar mengajar.

Dalam setiap upaya peningkatan kualitas pendidikan di tanah air, tidak dapat dilepaskan dari berbagai hal yang berkaitan dengan eksistensi guru itu sendiri. Sementara itu, Alma menyatakan

${ }^{1}$ R. K. Arifin, Implementasi Kebijakan Program Sertifikasi Guru, Jurnal Ilmu Politik 1 Nomor 2 (2008), 194-208. 
bahwa guru merupakan kunci keberhasilan sebuah lembaga pendidikan. ${ }^{2}$ Guru adalah sales agent dari lembaga pendidikan. Bukan itu saja dalam perspektif lebih luas, Asmani menyatakan bahwa guru adalah aktor utama perubahan di tengah masyarakat. ${ }^{3}$

Guru mempunyai peran sebagai profesional, jabatan ini menuntut peningkatan kecakapan dan mutu keguruan secara berkesinambungan. Guru berkualifikasi profesional adalah yang tahu secara mendalam tentang hal yang diajarkannya, cakap dalam cara mengajar efektif dan efisien serta mempunyai kepribadian. Guru juga harus memiliki kecakapan kerja baik dan kedewasaan berfikir tinggi, karena jabatan profesional guru merupakan posisi strategis dalam kehidupan dan pembangunan masyarakat. Guru harus dapat memantapkan posisi dan perannya melalui usaha-usaha mengembangkan kemampuan diri secara maksimal dan berkesinambungan. Selain karena pendidikan berlangsung sepanjang hayat. Hal ini didasarkan pada sistem pengajaran, materi pengajaran dan penyampaiannya perlu terus dikembangkan melalui upaya sistem pengembangan, sistem pengajaran, pembenahan isi serta teknologi organisasi materi pengajaran, pencarian pendekatan strategi, dan teknik pengajaran (perkembangan diri siswa) selalu perlu dikaji dan atau dikembangkan demi efektivitas serta efisiensi kerja pendidikan.

Mengacu pada uraian di atas, maka tidak berlebihan bahkan sangat tepat jika kemudian pemerintah mengeluarkan Undangundang Nomor 14 Tahun 2005 tentang Guru dan Dosen. Salah satu muatan yang paling mendapat perhatian dalam UU itu adalah sertifikasi. Pada pasal 1 ayat 11 dinyatakan "Sertifikasi adalah proses pemberian sertifikat pendidik untuk guru dan dosen." Implikasi bagi guru yang telah memperoleh sertifikat pendidik dinyatakan lebih lanjut dalam pasal 16 dinyatakan bahwa "Pemerintah akan memberikan tunjangan profesi kepada guru yang besarnya setara

2 B. Alma, Guru Profesional Menguasai Metode dan Terampil Mengajar, (Bandung: Alfabeta, 2009), 123.

${ }^{3}$ J. M. Asmani, Tips sukses PLPG Pendidikan dan Latihan Profesi Guru, (Yogyakarta: Diva Press, 2011) 
dengan 1 (satu) kali gaji pokok pada tingkat, masa kerja dan kualifikasi yang sama." Jadi, guru yang telah mendapat sertifikat pendidik akan memperoleh tunjangan profesi yakni tunjangan yang diberikan kepada guru yang memiliki sertifikat pendidik sebagai penghargaan atas profesionalitasnya. ${ }^{4}$ Program sertifikasi guru bertujuan untuk meningkatkan keprofesionalan guru, kesejahteraan dan martabat guru. Pasal 8 menyatakan guru wajib memiliki kualifikasi akademik, kompetensi, sertifikat pendidik, sehat jasmani dan rohani, serta memiliki kemampuan untuk mewujudkan tujuan pendidikan nasional. Kualifikasi akademik dimaksud sebagaimana pasal 9 adalah melalui pendidikan tinggi.

Walaupun peningkatan kesejahteraan guru bukan merupakan tujuan, tetapi lebih sebagai instrumen untuk meningkatkan kinerja guru agar berdampak terhadap peningkatan mutu pendidikan nasional. Peningkatan kesejahteraan bagi guru yang telah memenuhi standar kualifikasi akademik dan kompetensi akan berfungsi meningkatkan kinerja sesuai yang diharapkan. Oleh karena itu, khusus untuk tunjangan profesi pendidik hanya akan diterima oleh guru profesional yang ditandai dengan kepemilikan sertifikat profesi guru melalui program sertifikasi.

Penelitian terkait kebijakan sertifikasi guru pernah dilakukan oleh Arifin. Hasil penelitian menunjukkan bahwa ditemukan permasalahan sertifikasi guru SD yaitu tidak cukupnya waktu 24 jam yang disyaratkan untuk mendapat sertifikasi dikarenakan perencananaan penerimaan pegawai yang kurang baik sehingga mengakibatkan terjadi penggemukkan karyawan dan membuat guru kelas, agama dan olahraga di tempat penelitian tidak mendapat waktu yang cukup yaitu 24 jam yang mana menjadi salah satu syarat pencairan dana sertifikasi. $^{5}$

Persamaan penelitian terletak pada kajian implementasi kebijakan sertifikasi guru. Perbedaan penelitian terletak pada fokus penelitian. Penelitian itu berfokus pada implementasi kebijakan

\footnotetext{
${ }^{4}$ PP No. 41/2009 pasal 1 ayat 4 .

${ }^{5}$ R. K. Arifin, Implementasi Kebijakan Program Sertifikasi Guru, Jurnal Ilmu Politik, 1 Nomor 2 (2019), 194-208.
} 
program sertifikasi guru secara umum. Sementara penelitian ini berfokus pada implementasi kebijaka sertifikasi guru dalam meningkatkan kinerja guru di Kementeria Agama Kabupaten Tegal.

Penelitian lain yang memiliki relevansi dengan penelitian ini adalah milik Amrynudin, dkk dengan judul Implementasi Kebijakan Sertifikasi Guru di Kabupaten Tegal. Hasil penelitian menunjukkan bahwa Proses implementasi kebijakan sertifikasi guru SD di Kabupaten Tegal apabila dilihat dari ketepatan kebijakan, ketepatan pelaksanaan, ketepatan target, ketepatan lingkungan dan ketepatan proses adalah sudah sesuai dengan peraturan yang ada. Namun demikian, banyak guru yang belum siap melaksanakan kebijakan sertifikasi guru (berkualifikasi dibawah Si/DIV) pada saat sertifikasi mulai dicanangkan sehingga banyak guru yang harus kuliah terlebih dahulu untuk mendapatkan sertifikasi guru. ${ }^{6}$

Persamaan penelitian terletak pada kajian tentang implementasi kebijakan sertifikasi guru. Perbedaan penelitian terletak pada fokus kajian. Penelitian tersebut berfokus pada implementasi kebijakan sertifikasi guru di kabupaten Tegal. Sementara penelitian ini berfokus pada implementasi kebijakan sertifikasi guru dalam meningkatkan kinerja guru di Kementerian Agama Kabupaten Tegal.

Berdasarkan pemaparan tersebut, penelitian ini akan mendeskripsikan implementasi kebijakan sertifikasi guru di Kantor Kementerian Agama Kabupaten Tegal. Selain itu, penelitian ini akan melihat faktor-faktor apakah yang menghambat implementasi kebijakan sertifikasi guru di Kantor Kementerian Agama Kabupaten Tegal, serta implementasi kebijakan sertifikasi guru terhadap peningkatan kinerja guru di Kantor Kementerian Agama Kabupatan Tegal.

Penelitian ini menggunakan metode deskriptif kualitatif. Menurut Sugiyono metode penelitian kualitatif adalah metode

6 A. Amrynudin, Sundarso K \& A. Subowo, Implementasi Kebijakan Sertifikasi Guru di Kabupaten Tegal. Transformasi Nmomor 2, (2013), 51-57, Retrieved from http://ejurnal.unisri.ac.id/index.php/Transformasi/article/download/215/18o 
yang berlandaskan pada filsafat, yang digunakan untuk meneliti pada kondisi ilmiah (eksperimen) dan peneliti sebagai instrument, teknik pengumpulan data dan analisis yang bersifat kualitatif lebih menekan pada makna. ${ }^{7}$ Penelitian deskriptif adalah suatu penelitian yang bertujuan untuk menggambarkan atau memaparkan sesuatu hal, misalnya keadaan, kondisi, situasi, peristiwa, kegiatan dan lainlain. ${ }^{8}$ Pada penelitian ini metode deskriptif kualitatif digunakan untuk mendeskripsikan kebijakan tunjangan kinerja dan sertifikasi guru di Kantor Kementerian Agama Kabupaten Tegal. Sumber data penelitian adalah peristiwa dan informan. Teknik pengumpula data menggunakan teknik wawancara dan observasi. Teknik analisis data menggunaka model analisis interaktif. ${ }^{9}$ Data yang terkumpul kemudian dilakukan analisis data melalui kondensasi, disajikan sampai menghimpun dan menyimpulkan data terpilih sesuai kebutuhan penelitian.

\section{Pembahasan}

\section{Implementasi Kebijakan Sertifikasi Guru}

Implementasi merupakan sebuah proses interaksi antara penentuan tujuan dan tindakan untuk mencapai tujuan. Pada dasarnya implementasi adalah kemampuan untuk membangun hubungan dalam mata rantai sebab akibat agar kebijakan bisa berdampak. ${ }^{1}$ Implementasi kebijakan merupakan sclatu proses yang dinamis, di mana pelaksana kebijakan melakukan suatu aktivitas atau kegiatan, sehingga pada akhirnya akan mendapatkan suatu hasil yang sesuai dengan tujuan atau sasaran kebijakan. ${ }^{1}$ Ada tiga hal penting dari pengertian implementasi kebijakan, yaitu: (1) adanya tujuan atau

${ }^{7}$ Sugiyono, Metode Penelitian Kuantitatif, Kualitatif, dan RED, (Bandung: Alfabeta, 2018).

${ }^{8}$ S. Arikunto, Prosedur Penelitian Suatu Pendekatan Praktik, (Jakarta: PT. Asdi Mahasatya, 2006).

${ }_{9}^{9}$ M. B. Miles \& A. M. Huberman, Analisis Data Kualitatif, (T. R. Rohidi, Ed. c), (Jakarta: UI-Press, 2009).

1 W. Parsons, Public Policy, Pengantar Tebri dan Praktik Analisis Kebijakan, (Jakarta: Kencana Prenada Media Group, 20o6), 466.

1 L. Agustino, Dasar-Dasar Kebijakan Publik, (Bandung: Alfabeta, 20o8). 
sasaran kebijakan; (2) adanya aktivitas atau kegiatan pencapaian tujuan; dan (3) adanya hasil kegiatan.

Implementasi kebijakan dipandang dalam pengertian yang luas, merupakan tahap dari kebijakan segera setelah penetapan undang-undang. Ini mempunyai makna bahwa implementasi adalah pelaksanaan undang- undang dimana berbagai aktor, organisasi, prosedur dan teknik bekerja bersama untuk menjalankan kebijakan dalam upaya untuk meraih tujuan-tujuan kebijakan atau programprogram. Implementasi di sisi yang lain merupakan fenomena yang kompleks yang mungkin dapat dipahami sebagai suatu proses, suatu keluaran (output) maupun sebagai suatu dampak. ${ }^{1}$

Implementasi kebijakan adalah fase yang sangat menentukan di dalam proses kebijakan, bisa jadi fase ini menjadi tahap yang sangat krusial karena menyangkut dinamika, masalah atau problematika yang dihadapi sehingga akan berimbas pada dampak dan tujuan dari kebijakan publik. Oleh karena itu dibutuhkan proses implementasi yang efektif. Tanpa hal itu, keputusan-keputusan yang dibuat oleh pengambil keputusan tidak akan berhasil dan sukses.

Sesuai Edward III bahwa implementasi kebijakan dipengaruhi oleh empat variabel utama yakni; (1) komunikasi (communication); (2) sumber daya (resources); (3) disposisi (disposition); dan (4) struktur birokrasi (bureaucratic structure), maka untuk mengetahui implementasi keempat variabel di atas, harus dijabarkan kedalam beberapa dimensi dan indikator yang lebih spesifik.

\section{Komunikasi (Communication)}

Implementasi kebijakan ditinjau dari variabel komunikasi dengan seluruh dimensi dan indikatornya berjalan dengan baik. Dari dimensi transmisi seluruh indikator terpenuhi. Secara kognitif kebijakan sertifikasi guru dan pemberian tunjangan profesi guru telah diketahui semua stakeholder pendidikan di Kantor Kementerian Agama Kabupaten Tegal. Meskipun informasi

1 J. P. Lester \& J. J. Steward, Public Policy: An Evolutionari Approach, Belmont Wadsworth, (Belmont Wadsworth, 200o) 
dan pengetahuan tentang kebijakan sertifikasi guru sudah merata, akan tetapi tetap berbeda dalam tingkat pemahaman. Dapat dipastikan pemahaman kepala madrasah berbeda dengan staf. Pemahaman antar guru yang sudah mendapat tunjangan profesi guru akan berbeda dengan guru yang belum atau baru mengajukan permohonon mengikuti sertifikasi guru. Akan tetapi satu hal pasti, kebijakan tunjangan profesi guru sudah diketahui secara umum di kalangan Kantor Kementerian Agama Kabupaten Tegal. Kenyataan ini merupakan modal besar yang memperlancar implementasi kebijakan tunjangan profesi guru.

\section{Sumber Daya (Resources)}

Berdasarkan data variabel sumber daya, maka untuk menganalisis lebih lanjut perlu dipertegas bahwa dari dua dimensi sumber daya yakni manusia dan sarana ternyata untuk sarana tidak ada masalah karena ketersediaan sarana berupa komputer sudah memadai maupun perangkat administrasi lainnya. Untuk sumber daya manusia dalam hal ini pengelola atau staf yang diberikan tugas menangani administrasi guru terkait dengan tunjangan profesi guru, dari tiga indikator maka dua diantaranya sudah baik yakni jumlah pengelola dan kompetensi Informasi Teknologi (IT) pengelola sedangkan satu indikator yakni kemampuan staf pengelola dalam menjabarkan petunjuk kepala sekolah masih perlu ditingkatkan karena masih terkesan menunggu perintah dan belum ada inisiatif sendiri untuk proaktif menangani administrasi yang bermasalah atau berkas guru yang belum lengkap untuk pengusulan sertifikasi guru.

Tabel 1 Jumlah Guru Madrasah Kantor Kemanag Kabupaten Tegal

\begin{tabular}{|c|c|}
\hline MADRASAH & JUMLAH \\
\hline PNS Kemenag dan Madrasah & 429 \\
\hline Pengawas dan MIN & 244 \\
\hline Non PNS & 773 \\
\hline Total & $\mathbf{1 . 4 8 6}$ \\
\hline
\end{tabular}

Sumber : Kantor Kemenag Kabupaten Tegal 
Tabel 2 Jumlah Guru PAIS Kantor Kemanag Kabupaten Tegal

\begin{tabular}{|c|c|}
\hline PAIS & JUMLAH \\
\hline PNS & 363 \\
\hline NON PNS & 114 \\
\hline Total & 477 \\
\hline
\end{tabular}

Sumber: Kantor Kemenag Kabupaten Tegal

\section{Disposisi (Disposition)}

Disposisi kepala madrasah dalam mengimplementasikan kebijakan tunjangan profesi guru dari sisi internal dapat dijelaskan bahwa kepala madrasah menilai pemberian tunjangan profesi guru sangat positif dalam pengertian dapat meningkatkan kesejahteraan guru sekaligus meningkatkan Sumber Daya Manusia (SDM). Oleh karena itu, selaku kepala seksi, baik kepala seksi madrasah maupun Pendidikan Agama Islam (PAIS ) senantiasa memberikan motivasi kepada staf dan guru dalam rangka memperlancar proses administrasi pemberian tunjangan profesi.

Disposisi kepala seksi terhadap kebijakan tunjangan profesi guru secara internal sejalan dengan penilaian eksternal (penilaian dari guru dan pengawas). Data yang dikemukakan pengawas menjelaskan "Semua kelengkapan administrasi yang sudah disiapkan oleh staf pengelola, selanjutnya diperiksa dan ditandatangani oleh kepala sekolah kemudian diketahui pengawas pembina". Demikian pula data yang dikemukakan guru bahwa "Kepala madrasah sudah menunjukkan sikap tanggap dan peduli terhadap kepentingan guru untuk mengikuti sertifikasi guru”. Mencermati dan menganalisis data yang telah dikemukakan di atas, maka secara tegas dinyatakan bahwa dimensi disposisi kepala madrasah berhasil menjadi salah satu faktor penentu kelancaran implementasi kebijakan tunjangan profesi guru. Dengan kata lain dimensi disposisi memberikan kontribusi positif terhadap kelancaran proses implementasi kebijakan tunjangan profesi guru. Indikator kelancaran implementasi tunjangan profesi guru dari perspektif disposisi secara keseluruhan dapat diformulasikan 
menjadi dua aspek yakni kepala seksi memiliki sikap inisiatif dan responsif antisipatif. Kedua kata kunci ini menjadi penentu kelancaran implementasi kebijakan tunjangan profesi guru dari perspektif disposisi.

Sikap inisiatif kepala seksi antara lain dicirikan adanya motivasi yang diberikan kepala madrasah kepada guru yang mengikuti seleksi sertifikasi untuk secara cepat dan tepat membenahi proses administrasi kelengkapan berkas pengusulan calon guru tersertifikasi. Demikian pula pada staf pengelola administrasi senantiasa mendapat pengarahan dan bimbingan dari kepala sekolah untuk aktif menyelesaikan proses administrasi guru yang menerima tunjangan sertifikasi guru maupun pengusulan untuk mengikuti seleksi sertifikasi guru. Kepala sekolah senantiasa menunjukkan sikap proaktif mempertanyakan dan mengarahkan guru yang mengalami kendala administrasi pengusulan sertifikasi maupun perpanjangan penerimaan tunjangan profesi guru. Kepala sekolah sebagai pengambil kebijakan di satuan pendidikan diharapkan proaktif untuk mendorong staf pengelola untuk dapat menjemput bola karena salah satu kelemahan pengelola adalah menunggu bola. Agar keterlambatan administrasi dapat teratasi kepala sekolah dapat menegur langsung atau dengan cara pembinaan yang intensif kepada pengelola, atau mengambil sikap untuk mendelegasikan tugas dan tanggung jawab kepada Kepala Tata Usaha (KTU).

\section{Struktur Birokrasi (Bureaucratic Structure)}

Secara keseluruhan struktur birokarasi dalam kaitannya dengan kebijakan tunjangan sertifikasi guru sudah dikelola secara koordinatif. Dalam pengertian, seluruh unit yang terlibat dalam proses administrasi tunjangan profesi guru sudah melaksanakan tugas dan berkoordinasi satu sama lain. Akan tetapi jika dianalisis lebih jauh, maka tidak dapat dielakkan bahwa masih ditemukan beberapa keterbatasan yakni secara birokrasi kecepatan dan ketepatan pengelolaan administrasi pemberian tunjangan profesi guru masih perlu ditingkatkan karena pengiriman berkas-berkas 
guru seringkali terlambat. Keterlambatan ini disebabkan dua faktor yakni; faktor guru yang terlambat memasukkan berkas dan faktor keterbatasan kemampuan pengelola (cenderung menunggu) sebagaimana telah dijelaskan pada variabel sumber daya.

\section{Analisis Faktor Penghambat Implementasi Kebijakan Sertifikasi Guru di Kantor Kementerian Agama Kabupaten Tegal}

Untuk menjawab permasalahan faktor apakah yang menghambat implementasi kebijakan tunjangan profesi guru, maka terlebih dahulu dipetakan menjadi dua aspek, yakni aspek penghambat implementasi kebijakan dan aspek penghambat kebijakan pemberian tunjangan profesi guru. Faktor penghambat implementasi kebijakan pemberian tunjangan profesi guru secara kuantitatif tidak banyak. Penelitian ini berhasil mencatat dua faktor yang dapat dikedepankan, yakni: faktor masih ditemukannya keterlambatan pengiriman berkas pengusulan sertifikasi guru dan faktor keterlambatan pencairan dana tunjangan profesi guru. Jika temuan ini dianalisis lebih dalam maka dapat dinyatakan bahwa faktor yang pertama dapat dikategorikan sebagai faktor yang muncul dari internal satuan pendidikan sedangkan faktor yang kedua tidak sepenuhnya merefleksikan kondisi internal satuan pendidikan karena bagaimanapun juga keterlambatan pencairan dana sertifikasi bersifat kompleks karena berkaitan dengan institusi lain. Dengan kata lain secara administrasi kebijakan pencairan dana sertifikasi guru berada pada level pusat, provinsi, dan Kantor Kemenag termasuk unsur perbankan (bank).

Berdasarkan hasil penelitian di lapangan, diperoleh data yang menjadi faktor penghambat implementasi kebijakan tunjangan kinerja sertifikasi guru di Kantor Kementerian Agama Kabupaten Tegal, adalah sebagai berikut:

1. Faktor internal guru, yaitu: kemalasan, mentalitas, kurang kreatif, cepat merasa puas dengan hasil yang telah dicapai terutama hasil pembelajaran, dan guru belum konsisten memanfaatkan tunjangan profesi guru untuk peningkatan kinerja dan 
kompetensi guru.

2. Faktor eksternal guru:

a. Keterlambatan juknis penyaluran tunjangan profesi guru (TPG) baik TPG guru madrasah maupun guru PAIS.

b. Aplikasi yang sering troubel, untuk PAIS (aplikasi siaga), sedangkan untuk madrasah adalah (aplikasi simpatika).

c. Aplikasi siaga lebih sederahana dan mudah sedangkan aplikasi simpatika lebih rumit.

d. Keterlambatan mengumpulkan berkas TPG (presensi, surat keterangan beban kerja, dan lain-lain).

e. Kekurangan tim personel atau SDM yang bertugas mencairkan pencairan daftar isian pelaksanaan anggaran (DIPA).

f. Kendala pada prosedur pencairan DIPA.

g. Alokasi DIPA TPG yang kurang sehingga menjadi terhutang.

h. Penyesuaian data pegawai terkait kenaikan pangkat/ golongan dan grade.

i. Kecenderungan staf pengelola menunggu perintah dan kurang inisiatif.

\section{Kebijakan Sertifikasi Guru Terhadap Peningkatan Kinerja Guru di Kantor Kementerian Agama Kabupaten Tegal}

Guru merupakan tenaga professional yang bertugas merencanakan dan melaksanakan proses pembelajaran, melakukan bimbingan dan pelatihan, serta melakukan penelitian dan pengabdian masyarakat terutama bagi dosen di perguruan tinggi. Hal ini tidak dapat disangkal karena dunia lembaga pendidikan formal adalah kehidupan guru. Sebagian besar waktunya di sekolah, sedangkan sisanya di rumah dan masyarakat.

Guru profesional tidak hanya dituntut untuk menguasai bidang ilmu, bahan ajar, metode pembelajaran, memotivasi peserta didik, memiliki keterampilan yang tinggi dan wawasan yang luas terhadap dunia pendidikan, tetapi juga harus memiliki pemahaman yang mendalam tentang hakikat manusia dan masyarakat. Hakikathakikat ini akan melandasi pola pikir dan budaya kerja guru, serta 
loyalitas terhadap profesi pendidikan. Mulyasa mengemukakan bahwa profesionalisme guru adalah salah satu usaha peningkatan mutu pendidikan, dengan guru yang profesional tentunya akan menghasilkan peserta didik yang baik pula. ${ }^{1}$

Sehubungan dengan peningkatan profesionalisme guru, pemerintah terus berupaya mencari alternatif untuk meningkatkan kualitas dan kinerja profesi guru. Salah satu terobosan yang sedang dilakukan adalah melakukan standar kompetensi dan sertifikasi guru. Dalam hal ini, sebagaimana yang dikemukakan oleh Alma bahwa pengembangan profesionalisme guru merupakan sesuatu yang tidak bisa ditawar lagi untuk dapat meningkatkan mutu pendidikan. ${ }^{1}$

Usaha lainnya yang telah dilakukan oleh pemerintah untuk meningkatkan mutu pendidikan nasional adalah melakukan pengembangan kurikulum nasional dan lokal, peningkatan kompetensi guru melalui pelatihan, pengadaan buku dan alat pelajaran, pengadaan dan perbaikan sarana dan prasarana pendidikan, peningkatan mutu manajemen sekolah dan sertifikasi guru.

Melalui sertifikasi guru diharapkan mampu meningkatkan profesionalisme guru yang berdampak pada perbaikan kinerja guru. Sertifikasi adalah pemberian sertifikat pendidikan untuk guru. Sertifikasi merupakan bukti formal sebagai pengakuan yang diberikan kepada guru dan dosen sebagai tenaga professional.

Dengan demikian sertifikasi sebagai proses pemberian pengakuan bahwa seseorang telah memiliki kompetensi untuk melaksanakan pendidikan pada satuan pendidikan tertentu setelah lulus uji kompetensi yang dirancang untuk mengungkapkan penguasaan kompetensi seseorang sebagai landasan diadakan sertifikasi guru. Sertifikasi dilaksanakan melalui uji kompetensi yang dilakukan dalam bentuk penilaian portofolio, yang merupakan

1 E. Mulyasa. Menjadi Guru Profesional Menciptảkan Pembelajaran Kreatif dan Menyenangkan, (Bandung: Remaja Rosdakarya, 2005).

B. Alma. Guru Profesional Menguasai Metode dan Terampil Mengajar, (Bandung: Alfabeta, 2009), 124. 
pengakuan atas pengalaman profesional guru dalam bentuk penilaian terhadap dokumen-dokumen yang mencerminkan kompetensi guru. ${ }^{1}$

Sertifikasi merupakan angin segar bagi para guru, karena dengan adanya sertifikat pendidik, pemerintah menyediakan tunjangan sertifikasi sebesar satu kali gaji pokok. Diharapkan dengan memberikan tunjangan tersebut, dapat meningkatkan kinerja guru kearah yang lebih baik sehingga prestasi siswa meningkat juga. Dengan demikian jika kinerja guru dan profesionalisme guru meningkat, selanjutnya dapat dipastikan mutu pendidikan di Indonesia akan meningkat juga. Tujuan dari sertifikasi guru untuk: (1) menentukan kelayakan guru dalam melaksanakan tugas sebagai agen pembelajaran dan mewujudkan tujuan pendidikan nasional, (2) meningkatkan proses dan mutu hasil pendidikan, (3) meningkatkan martabat guru, (4) meningkatkan profesionalitas guru, (5) meningkatkan kesejahteraan guru.

Kinerja guru yang baik akan memberikan kontribusi yang optimal terhadap pencapaian tujuan pendidikan nasional, untuk itu selaku pengajar guru dituntut melaksakan tugasnya dengan bertanggung jawab terhadap proses pembelajaran. Berkaitan dengan hal ini, Mangkunegara mengemukakan bahwa kinerja guru adalah hasil kerja secara kualitas dan kuantitas yang hendak dicapai oleh guru dalam melaksanakan tugasnya sesuai dengan tanggung jawabnya selaku pengajar. Dengan kata lain guru haruslah semaksimal mungkin mengerjakan tugasnya tanpa mengenal kata menyerah dalam melaksanakan tugasnya. Kinerja juga diartikan sebagai prestasi yang nampak sebagai keberhasilan kerja dari seseorang, namun prestasi yang dimaksud bukanlah prestasi yang berkaitan dengan banyaknya kejuaraan yang diperoleh guru tersebut melainkan keberhasilan yang salah satunya tampak dari suatu proses belajar mengajar. Keberhasilan kinerja guru juga ditentukan dengan pekerjaan serta kemampuan seseorang dalam bidang tersebut. Keberhasilan kerja juga berkaitan dengan kepuasan kerja

1 M. Muslich, Sertifikasi Guru Menuju Profesiơnalime Pendidik, (Jakarta: Bumi Aksara, 2007), 21. 
seseorang. ${ }^{1}$ Kinerja guru yang baik merupakan fmplementasi dari rencana yang telah ditetapkan, implementasi kinerja yang dilakukan oleh guru yang memiliki kecakapan, pengalaman, kesungguhan, kompetensi, motivasi, tanggung jawab dan kepentingan dalam mencapai tujuan.

Dalam Undang-Undang No. 14 tahun 2005 pasal 1 disebutkan bahwa "Guru adalah pendidik profesional dengan tugas utama mendidik, mengajar, membimbing, mengarahkan, melatih dan mengevaluasi peserta didik pada pendidikan anak usia dini jalur pendidikan formal, pendidikan dasar dan pendidikan menengah". Lebih lanjut dalam pasal 25 ditegaskan bahwa beban kerja guru mencakup kegiatan pokok yaitu merencanakan pembelajaran, melaksanakan pembelajaran, menilai hasil pembelajaran, membimbing dan melatih peserta didik, serta melaksanakan tugas tambahan.

Berdasarkan isyarat dari pasal tersebut diatas dapat dipahami bahwa kinerja guru adalah unjuk kerja yang ditunjukkan oleh guru baik secara kualitas maupun kuantitas yang ditampilkan selama proses belajar mengajar berlangsung dengan indikator meliputi kemampuan merencanakan pembelajaran, melaksanakan pembelajaran, dan mengevaluasi pembelajaran secara efektif.

Hal ini senada dengan pendapat Sanjaya bahwa kinerja guru berkaitan dengan tugas perencanaan, pengelolaan pembelajaran dan penilaian hasil belajar siswa. Sebagai perencana maka guru harus mampu mendesain pembelajaran yang sesuai dengan kondisi di lapangan. Sebagai pengelola maka guru harus mampu menciptakan iklim pembelajaran yang kondusif sehingga siswa dapat belajar dengan baik, dan sebagai evaluator maka guru harus mampu melaksanakan penilaian proses dan hasil belajar siswa. ${ }^{1}$

Berdasarkan pendapat tersebut tergambar bahwa kinerja guru adalah kemampuan yang ditunjukkan oleh guru dalam melaksanakan tugas atau pekerjaannya. Dengan kata lain, kinerja guru dalam

1 A. Mangkunegara, Manajemen Sumber Daya Manusia, (Bandung: Remaja Rosda Karya, 2007), 47.

1 W. Sanjaya, Pembelajaran dalam Implementasi Kurikulum Berbasis Kompetensi, (Jakarta: Prenada Media, 2005). 
proses belajar mengajar adalah kemampuan guru dalam melaksanakan tugasnya sebagai pengajar yang memiliki keahlian mendidik peserta didik dalam rangka pembinaan peserta didik untuk tercapai tujuan pendidikan. Kinerja guru dikatakan baik dan memuaskan apabila tujuan yang dicapai dalam kegiatan pembelajaran telah sesuai dengan standar yang sudah ditetapkan.

Oleh karena itu, untuk mencapai suatu kinerja yang optimal guru haruslah berusaha mengembangkan serta menciptakan situasi yang ada di lingkungan sekolah sesuai dengan aturan yang berlaku. Guru benar-benar dituntut untuk memiliki kinerja yang tinggi, karena dengan memiliki kinerja yang tinggi maka tingkat sumber daya manusia di Indonesia akan semakin baik apalagi di kalangan generasi muda sehingga terciptanya generasi yang cerdas, dan mampu menjawab tantangan di masa yang depan.

Dalam kenyataannya bahwa maksud dan tujuan dari pemberian sertifikasi guru, tidak sebanding dengan maksud dan tujuan utamanya yaitu peningkatan kinerja guru, tetapi lebih bersfat konsumtif. Untuk menjawab permaslahan tersebut maka harus dilakukan program Pengembangan Keprofesian Berkelanjutan (PKB) bagi guru yang telah mendapatlkan sertifikasi secara maksimal.

Berdasarkan Peraturan Menteri Pendayagunaan Aparatur Negara (Men PAN dan RB) nomor 16 Tahun 2009, pasal 11 ayat c, bahwa komponen Pengembangan Keprofesian Berkelanjutan (PKB), terdiri dari :

1. Pengembangan diri, meliputi:

a. Diklat fungsional

b. Kegiatan kolektif guru

2. Publikasi ilmiah, meliputi:

a. Presentasi pada forum ilmiah

b. Publikasi ilmiah atas hasil penelitian atau gagasan ilmu di bidang pendidikan formal

c. Publikasi buku pelajaran, buku pengayaan dan pedoman guru

3. Karya Inovatif, meliputi: 
a. Menemukan teknologi tepat guna

b. Menemukan/menciptakan karya seni

c. Membuat/memodifikasi alat pelajaran/peraga/praktikum

d. Mengikuti pengembangan penyusunan standar, pedoman, soal dan sejenisnya

Bila Pengembangan Keprofesian Berkelanjutan (PKB) ini dijalankan secara maksimal maka kinerja guru akan terwujud dan tujuan dari pendidikan nasional akan tercapai.

Implementasi kebijakan sertifikasi guru di Kantor Kementerian Agama Kabupaten Tegal berjalan dengan baik. Berdasarkan model implementasi kebijakan Edward III yang terdiri atas empat variabel yakni komunikasi, sumber daya, disposisi, dan struktur birokrasi, maka hanya sumber daya pada staf pengelola yang belum mampu menjabarkan petunjuk kepala seksi dan struktur birokrasi pada dimensi kecepatan dan ketepatan pengiriman berkas yang masih perlu ditingkatkan.

Faktor penghambat implementasi kebijakan sertifikasi guru di Kantor Kementerian Agama Kabupaten Tegal adalah kecenderungan staf pengelola menunggu perintah dan kurang inisiatif. Sementara itu hambatan peningkatkan kinerja guru adalah kemalasan, mentalitas, kurang kreatif, cepat merasa puas dengan hasil yang telah dicapai terutama hasil pembelajaran, dan guru belum konsisten memanfaatkan tunjangan profesi guru untuk peningkatan kinerja dan kompetensi guru. Faktor lain yang menjadi penghambat seperti kekurangan SDM, aplikasi, penyesuaian kenaikan pangkat, kekurangan alokasi anggaran DIPA, serta keterlambatan pengumpulan berkas persyaratan pencairan TPG.

\section{Simpulan}

Berdasarkan penelitian yang telah dilaksanakan dapat disimpulkan bahwa implementasi kebijakan sertifikasi guru di Kantor Kementerian Agama Kabupaten Tegal berjalan dengan baik. Berdasarkan model implementasi kebijakan Edward III yang terdiri atas empat variabel yakni komunikasi, sumber daya, disposisi, dan struktur birokrasi, maka hanya sumber daya pada dimensi staf 
pengelola belum mampu menjabarkan petunjuk kepala seksi dan struktur birokrasi pada dimensi kecepatan dan ketepatan pengiriman berkas yang masih perlu ditingkatkan.

Faktor penghambat implementasi kebijakan sertifikasi guru di Kantor Kementerian Agama Kabupaten Tegal adalah kecenderungan staf pengelola menunggu perintah dan kurang inisiatif. Sementara itu hambatan meningkatkan kinerja guru adalah kemalasan, mentalitas, kurang kreatif, cepat merasa puas dengan hasil yang telah dicapai terutama hasil pembelajaran, dan guru belum konsisten memanfaatkan tunjangan profesi guru untuk peningkatan kinerja dan kompetensi guru. Serta Faktor lain seperti kekurangan SDM, aplikasi, penyesuaian kenaikan pangkat, kekurangan alokasi anggaran DIPA, keterlambatan pengumpulan berkas persyaratan pencairan TPG.

Melalui program peningkatan kualitas kinerja guru terutama terhadap program sertifikasi guru, guru diharapkan mampu meningkatkan kompetensi sebagai agen pembelajaran meliputi kompetensi pedagogik, kompetensi kepribadian, kompetensi sosial, dan kompetensi professional, yang mana kesemuanya itu akan berdampak pada perbaikan kinerja guru. Sertifikasi merupakan bukti formal sebagai pengakuan yang diberikan kepada guru dan dosen sebagai tenaga profesional. Maka dalam rangka peningkatan kinerja guru, PKB perlu dilaksanakan secara maksimal.

\section{Referensi}

Agustino, L., Dasar-Dasar Kebijakan Publik. Bandung: Alfabeta, 2008.

Alma, B., Guru Profesional Menguasai Metode dan Terampil Mengajar, Bandung: Alfabeta, 2009.

Amrynudin, A. K., Sundarso, \& Subowo, A., Implementasi Kebijakan Sertifikasi Guru di Kabupaten Tegal, 2013. Retrieved from http://ejurnal.unisri.ac.id/index.php/Transformasi/article/dow nload $/ 215 / 180$ 
Arifin, R. K., Implementasi Kebijakan Program Sertifikasi Guru, Jurnal Ilmu Politik, 1(2), 2019.

Arikunto, S., Prosedur Penelitian Suatu Pendekatan Praktik, Jakarta: PT. Asdi Mahasatya, 2006.

Asmani, J. M., Tips sukses PLPG Pendidikan dan Latihan Profesi Guru, Yogyakarta: Diva Press, 2011.

Lester, J. P., \& Steward, J. J., Public Policy : An Evolutionari Approach, Belmont Wadsworth, Belmont Wadsworth, 2000.

Mangkunegara, A., Manajemen Sumber Daya Manusia, Bandung: Remaja Rosda Karya, 2007.

Miles, M. B., \& Huberman, A. M., Analisis Data Kualitatif. (T. R. Rohidi, Ed.), Jakarta: UI-Press, 2009.

Mulyasa, E., Menjadi Guru Profesional Menciptakan Pembelajaran Kreatif dan Menyenangkan, Bandung: Remaja Rosdakarya, 2005.

Muslich, M., Sertifikasi Guru Menuju Profesionalime Pendidik, Jakarta: Bumi Aksara, 2007.

Parsons, W., Public Policy, Pengantar Teori dan Praktik Analisis Kebijakan, Jakarta: Kencana Prenada Media Group, 2006.

Sanjaya, W., Pembelajaran dalam Implementasi Kurikulum Berbasis Kompetensi, Jakarta: Prenada Media, 2005.

Sugiyono, Metode Penelitian Kuantitatif, Kualitatif, dan REDD, Bandung: Alfabeta, 2018. 